\title{
Purwarupa Sistem Pakar Dengan Metode Forward Chaining Dan Certainty Factor Untuk Mendeteksi Penyakit Kanker Payudara
}

\author{
Eka Widyawati ${ }^{1}$, Ari Fadli ${ }^{* 2}$, Muhammad Syaiful Aliim ${ }^{3}$
}

1,2,3 Teknik Elektro, Fakultas Teknik, Universitas Jenderal Soedirman, Indonesia

Email : ${ }^{1}$ eka.widyawati022@ @mhs.unsoed.ac.id, ${ }^{2}$ arifadli@ unsoed.ac.id, ${ }^{3}$ muhammad.syaiful.aliim@unsoed.ac.id

\begin{abstract}
Abstrak
Sistem pakar adalah sebuah sistem yang berusaha mengadopsi pengetahuan manusia ke komputer, agar komputer dapat menyelesaikan suatu permasalahan seperti yang biasanya dilakukan oleh para ahli. Kanker merupakan penyakit yang disebabkan oleh pertumbuhan sel yang tidak normal dan tidak terkendali serta menekan sel-sel yang normal. Sejumlah sel dalam payudara tumbuh dan berkembang dengan tidak terkendali inilah yang disebut dengan kanker payudara. Oleh karena itu, penelitian ini mencoba untuk membangun sebuah aplikasi agar dapat mengetahui gejala awal dari penyakit kanker payudara. Aplikasi ini berbasis website dengan menggunakan metode waterfall yang merupakan suatu metode dalam pengembangan perangkat lunak dengan melalui 5 tahapan yaitu, requirement analysis and definition, system and software design, implementation and unit testing, integration and system testing, dan operation and maintenance. Website ini diimplementasikan dengan menggunakan bahasa pemrograman PHP dan basis data MySQL. Pengambilan hasil kesimpulan untuk hasil diagnosa didasarkan pada hasil penelusuran secara forward chaining dan perhitungan secara certainty factor. Pengujian sistem pakar dilakukan dengan menggunakan black-box testing dan usability testing. Pengujian dengan metode black-box terhadap fungsionalitas dari setiap bagian aplikasi sistem pakar, didapatkan hasil yang sudah sesuai dengan tujuan yang diharapkan. Sedangkan pengujian dengan metode usability testing terhadap 50 responden yang menggunakan aplikasi sistem pakar, didapatkan hasil penerimaan yang baik memenuhi kelima aspek usability testing yaitu learnability, efficiency, memorability, errors, dan satisfaction dengan nilai persentase sebesar $85 \%$.
\end{abstract}

Kata kunci: Kanker Payudara, Sistem Pakar, Website

\section{Prototypes Expert System Using Forward Chaining And Certainty Factor to Detect Breast Cancer Disease}

\begin{abstract}
An expert system is a system that tries to adopt human knowledge to a computer, so that computers can solve a problem as is usually done by experts. Cancer is a disease caused by abnormal and uncontrolled cell growth and suppressing normal cells. A number of cells in the breast grow and develop uncontrollably which is called breast cancer. Therefore, this study tries to build an application in order to find out the early symptoms of breast cancer. This website-based application uses the waterfall method which is a method in software development through 5 stages, namely, requirements analysis and definition, system and software design, implementation and unit testing, integration and system testing, and operation and maintenance. This website is implemented using the PHP programming language and MySQL database. Drawing conclusions for the results of the diagnosis is based on the results of forward chaining searches and calculations with certainty factor. Expert system testing is carried out using black-box testing and usability testing. Testing with the black-box method of the functionality of each part of the expert system application, obtained results that are in accordance with the expected objectives. While testing with the usability testing method on 50 respondents who used an expert system application, it was found that good acceptance results fulfilled the five aspects of usability testing, namely learnability, efficiency, memorability, errors, and satisfaction with a percentage value of $85 \%$.
\end{abstract}

Keywords: Breast Cancer, Expert System, Website

\section{PENDAHULUAN}

Sistem pakar (expert system) adalah sebuah sistem yang berusaha mengadopsi pengetahuan manusia ke komputer, agar komputer dapat menyelesaikan suatu permasalahan seperti yang biasanya dilakukan oleh para ahli (pakar) [1]. Salah satu implementasi yang diterapkan sistem pakar dalam bidang kesehatan ialah untuk konsultasi, 
analisis, diagnosis, membantu pengambilan keputusan dan lain-lain. Salah satu dari kegunaan sistem pakar adalah untuk mendiagnosa penyakit kanker.

Kanker merupakan penyakit yang disebabkan oleh pertumbuhan sel yang tidak normal dan tidak terkendali serta menekan sel-sel yang normal. Pertumbuhan sel yang tidak normal ini dapat membentuk sebuah benjolan yang umumnya dikenal dengan istilah tumor. Tumor dibagi menjadi dua golongan besar, yaitu tumor jinak dan tumor ganas atau kanker [2].

Kanker dapat menyerang semua lapisan masyarakat tanpa mengenal umur dan jenis kelamin. Kanker merupakan pembunuh nomor 2 (dua) di dunia, dan kebanyakan kaum wanita cukup rentan terhadap serangan kanker, terutama pada organ vital seperti payudara dan organ reproduksi seperti rahim, indung telur dan vagina. The American Cancer Society memperkirakan bahwa pada tahun 2017, sekitar 252.710 wanita akan didiagnosis dengan kanker payudara invasif dan sekitar 40.610 akan meninggal akibat penyakit ini.

Melihat besarnya akibat yang ditimbulkan oleh kanker payudara dipandang dari segi harapan hidup, angka kesembuhan, lama penderitaan, serta tingginya biaya pengobatan, maka penting bagi semua orang terutama kaum wanita untuk mengetahui gejala awal dan faktor-faktor risiko kanker payudara agar dapat dilakukan upaya pencegahan pemicu munculnya penyakit tersebut dan mengambil tindakan yang tepat untuk memberantasnya. Pencegahan penyakit kanker sangat diperlukan tetapi karena terbatasnya jumlah dokter dan ahli, di sinilah perannya berpengaruh besar karena banyaknya pasien yang harus ditangani.

Metode forward chaining berarti menggunakan himpunan aturan kondisi-aksi. Dalam metode ini data digunakan untuk menentukan aturan (rule) mana yang akan dijalankan, kemudian aturan tersebut dijalankan. Proses menambahkan data ke memori kerja. Proses diulang sampai ditemukan suatu hasil [3]. Sedangkan, metode certainty factor merupakan nilai parameter klinis yang diberikan MYCIN untuk menunjukkan besarnya kepercayaan. Ada 2 macam faktor kepastian yang digunakan, yaitu faktor kepastian yang diisikan oleh pakar/ahli bersama dengan aturan dan faktor kepastian yang diberikan oleh pengguna [4]. Metode ini sangat cocok untuk mendiagnosa sesuatu yang belum pasti kebenarannya.

Berdasarkan hal tersebut, dalam penelitian ini akan dikembangkan aplikasi berbasis website yang dapat digunakan untuk mendeteksi kanker payudara. Sehingga, aplikasi ini dapat dijadikan salah satu upaya sosialisasi kepada masyarakat khususnya kaum wanita agar tidak terlambat dalam mengetahui gejala-gejala kanker payudara dan dapat dilakukan tindakan lanjut sebelum sel kanker tersebut menyebar ke seluruh tubuh. Dengan itu, kita dapat mengurangi besarnya angka kematian yang semakin meningkat setiap tahunnya.

\section{METODE PENELITIAN}

Model air terjun (waterfall) sering juga disebut model sekuensial linier (sequential linear) atau alur hidup klasik (classic life cycle). Model air terjun menyediakan pendekatan alur hidup perangkat lunak secara sekuensial atau terurut dimulai dari analisis, desain, pengodean, pengujian dan tahap pendukung (support) [5]. Gambar-1 merupakan tahapan yang terdapat dalam metode waterfall, yaitu [6]:

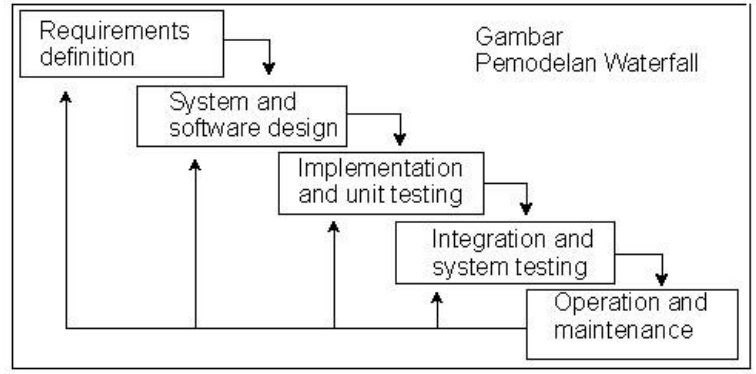

Gambar 1. Tahapan metode waterfall

\subsection{Requirement analysis and definition}

Tahap ini akan mendefinisikan tujuan umum dan ruang lingkup sistem pakar, serta menjelaskan beberapa hal yang berkaitan dalam membangun sebuah sistem pakar untuk penyakit kanker payudara.

\section{Penilaian keadaan}

Penilaian keadaan dilakukan sebagai bahan pertimbangan apakah sistem pakar yang akan dibangun layak untuk digunakan dan dibutuhkan. Penilaian keadaan ini dilakukan terhadap dua hal yaitu:

1. Kelayakan Teknis

Kelayakan teknis dilakukan dalam dua hal yaitu ketersediaan teknologi dan ketersediaan data. 
2. Kelayakan Operasi

Kelayakan operasi dilakukan untuk mengukur apakah sistem pakar nantinya dapat di operasikan dengan baik atau tidak.

\section{Pengumpulan data}

Proses pengumpulan data-data atau akusisi pengetahuan diperoleh dengan melakukan wawancara oleh narasumber dan juga studi literatur yang bersumber dari "Panduan Penatalaksanaan Kanker Payudara [7]", dan "Sistem Pakar Diagnosis Penyakit Kanker Payudara Dan Cara Penanganannya [8]", serta internet.

1. Data Penyakit

Data-data penyakit ini dapat dilihat pada tabel-1:

\begin{tabular}{cl}
\multicolumn{2}{c}{ Tabel 1. Data Penyakit } \\
\hline Kode & \multicolumn{1}{c}{ Nama Penyakit } \\
\hline P01 & Kanker Payudara Stadium 0 \\
P02 & Kanker Payudara Stadium 1 \\
P03 & Kanker Payudara Stadium 2A \\
P04 & Kanker Payudara Stadium 2B \\
P05 & Kanker Payudara Stadium 3A \\
P06 & Kanker Payudara Stadium 3B \\
P07 & Kanker Payudara Stadium 3C \\
P08 & Kanker Payudara Stadium 4 \\
\hline
\end{tabular}

2. Data Gejala

Data-data gejala ini dapat dilihat pada tabel-2:

\begin{tabular}{cl}
\multicolumn{1}{c}{ Tabel 2. Data Gejala } \\
\hline Kode & \multicolumn{1}{c}{ Nama Penyakit } \\
\hline G01 & Kulit payudara berwarna kemerahan \\
G02 & Terjadi pembengkakan pada payudara \\
G03 & Payudara mengoreng atau menjadi borok (luka-luka) \\
G04 & Tidak terdapat benjolan pada payudara \\
G05 & Tidak terdapat metastasis pada kelenjar getah bening regional di ketiak/aksila \\
G06 & Terdapat benjolan pada payudara berukuran diameter $2 \mathrm{~cm}$ atau kurang \\
G07 & Terdapat benjolan pada payudara berukuran diameter $2 \mathrm{~cm}$ hingga $5 \mathrm{~cm}$ \\
G08 & Terdapat metastasis ke kelenjar getah bening regional di ketiak/aksila yang dapat digerakkan \\
G09 & Terdapat benjolan pada payudara berukuran diameter lebih dari $5 \mathrm{~cm}$ \\
G10 & Terdapat metastasis kelenjar getah bening regional di ketiak/aksila yang sulit digerakkan \\
G11 & Terdapat benjolan pada payudara ukuran berapa saja \\
G12 & Terdapat metastasis ke kelenjar getah bening di atas tulang selangka/di dekat tulang sternum \\
G13 & Tidak terdapat metastasis jauh \\
G14 & Terdapat metastasis jauh \\
\hline
\end{tabular}

\section{Representasi pengetahuan}

Metode pelacakan yang digunakan pada penelitian ini ialah forward chaining atau penalaran dimulai dari fakta terlebih dahulu untuk menguji kebenaran hipotesis. Bentuk representasi ini dapat dikatakan sebagai hubungan implikasi dari premis (jika, $I F$ ) yang didapat dari data gejala penyakit dan bagian konklusi (maka, THEN) sebagai penyakit kanker payudara. Pada tabel-3 dapat dilihat bahwa terdapat aturan metode forward chaining.

Tabel 3. Aturan forward chaining

\begin{tabular}{ccc}
\hline Kode & Kode Penyakit & Kode Gejala \\
\hline R01 & P01 & G04, G05, G13 \\
R02 & P02 & G05, G13, G06 \\
R03 & P03 & G13, G07, G08 \\
R04 & P04 & G13, G08, G09 \\
R05 & P05 & G13, G09, G10 \\
R06 & P06 & G02, G13, G10, G11, G03, G01 \\
R07 & P07 & G02, G13, G11, G03, G01, G12 \\
R08 & P08 & G02, G11, G03, G01, G12, G14 \\
\hline
\end{tabular}

Metode perhitungan yang digunakan pada penelitian ini ialah certainty factor, merupakan nilai yang muncul untuk menjelaskan besar kepercayaan dari setiap gejala pada penyakit kanker payudara. Pada tabel-4 dapat dilihat bahwa terdapat aturan metode certainty factor. 


\begin{tabular}{|c|c|c|c|}
\hline Kode & Kaidah Produksi & MB & MD \\
\hline R01 & IF G04 THEN P01 & 0.4 & 0.0 \\
\hline R02 & IF G05 THEN P01 & 0.8 & 0.2 \\
\hline R03 & IF G13 THEN P01 & 0.8 & 0.2 \\
\hline R04 & IF G05 THEN P02 & 0.4 & 0.2 \\
\hline R05 & IF G13 THEN P02 & 0.8 & 0.2 \\
\hline R06 & IF G06 THEN P02 & 0.8 & 0.0 \\
\hline R07 & IF G13 THEN P03 & 0.6 & 0.2 \\
\hline R08 & IF G07 THEN P03 & 0.8 & 0.0 \\
\hline R09 & IF G08 THEN P03 & 0.4 & 0.2 \\
\hline $\mathrm{R} 10$ & IF G13 THEN P04 & 0.6 & 0.2 \\
\hline R11 & IF G08 THEN P04 & 0.4 & 0.2 \\
\hline $\mathrm{R} 12$ & IF G09 THEN P04 & 0.4 & 0.0 \\
\hline $\mathrm{R} 13$ & IF G13 THEN P05 & 0.4 & 0.2 \\
\hline $\mathrm{R} 14$ & IF G09 THEN P05 & 0.6 & 0.0 \\
\hline $\mathrm{R} 15$ & IF G10 THEN P05 & 0.6 & 0.2 \\
\hline $\mathrm{R} 16$ & IF G02 THEN P06 & 0.4 & 0.0 \\
\hline $\mathrm{R} 17$ & IF G13 THEN P06 & 0.4 & 0.2 \\
\hline $\mathrm{R} 18$ & IF G10 THEN P06 & 0.6 & 0.2 \\
\hline $\mathrm{R} 19$ & IF G11 THEN P06 & 0.8 & 0.0 \\
\hline $\mathrm{R} 20$ & IF G03 THEN P06 & 0.4 & 0.0 \\
\hline $\mathrm{R} 21$ & IF G01 THEN P06 & 0.4 & 0.0 \\
\hline $\mathrm{R} 22$ & IF G02 THEN P07 & 0.6 & 0.0 \\
\hline $\mathrm{R} 23$ & IF G13 THEN P07 & 0.4 & 0.2 \\
\hline $\mathrm{R} 24$ & IF G11 THEN P07 & 0.8 & 0.0 \\
\hline $\mathrm{R} 25$ & IF G03 THEN P07 & 0.4 & 0.0 \\
\hline $\mathrm{R} 26$ & IF G01 THEN P07 & 0.4 & 0.0 \\
\hline $\mathrm{R} 27$ & IF G12 THEN P07 & 0.4 & 0.2 \\
\hline R28 & IF G02 THEN P08 & 0.4 & 0.0 \\
\hline R29 & IF G11 THEN P08 & 0.8 & 0.0 \\
\hline $\mathrm{R} 30$ & IF G03 THEN P08 & 0.4 & 0.0 \\
\hline R31 & IF G01 THEN P08 & 0.4 & 0.0 \\
\hline $\mathrm{R} 32$ & IF G12 THEN P08 & 0.4 & 0.2 \\
\hline R33 & IF G14 THEN P08 & 0.8 & 0.2 \\
\hline
\end{tabular}

\subsection{System and software design}

Tahap ini merupakan tahapan perancangan kebutuhan sistem baik perangkat keras maupun perangkat lunak dengan membentuk model sistem secara keseluruhan mulai dari proses akusisi pengetahuan pakar ke sistem, representasi pengetahuan, kaidah produksi yang digunakan hingga pemilihan metode inferensi yang digunakan untuk pengambilan kesimpulan.

Data flow diagram merupakan alat pemodelan dari proses analisis kebutuhan perangkat lunak. Dalam DFD dibahas fungsi-fungsi apa saja yang diperlukan oleh suatu sistem dan aliran data yang terdapat di antara proses di dalamnya [9]. DFD level 0 sistem pakar penyakit kanker payudara dapat dilihat pada gambar-2.

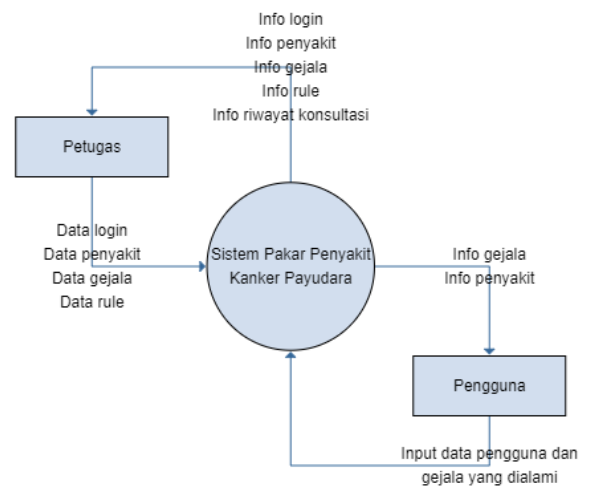

Gambar 2. DFD level 0 
DFD level 1 sistem pakar penyakit kanker payudara dapat dilihat pada gambar-3.

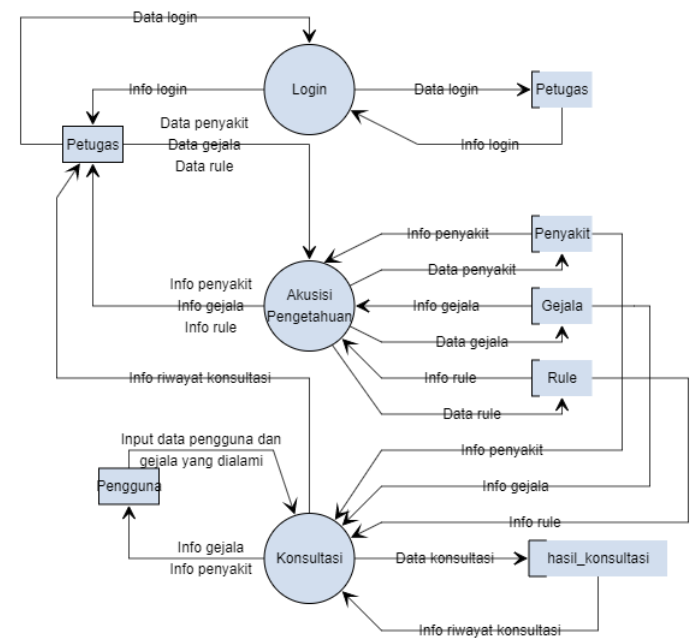

Gambar 3. DFD level 1

DFD level 2 dari data penyakit sistem pakar penyakit kanker payudara dapat dilihat pada gambar-4.

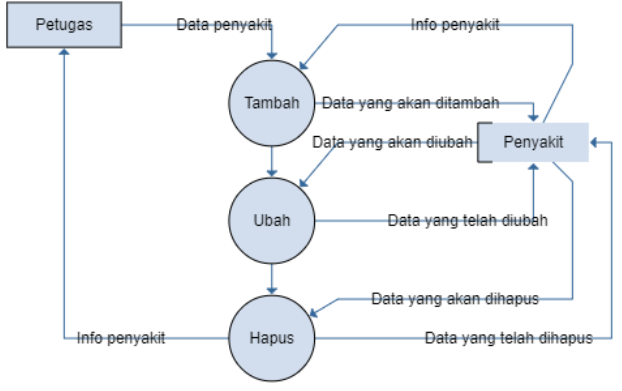

Gambar 4. DFD level 2(penyakit)

DFD level 2 dari data gejala sistem pakar penyakit kanker payudara dapat dilihat pada gambar-5.

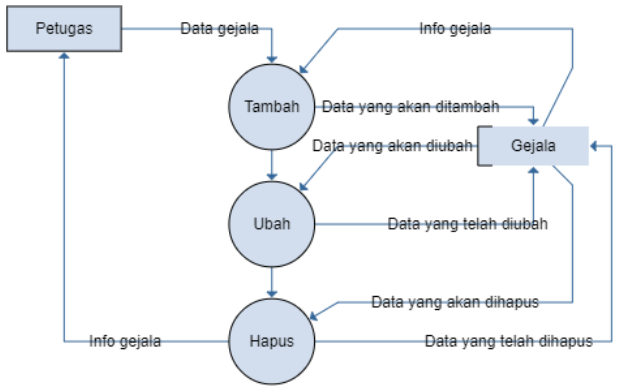

Gambar 5. DFD level 2(gejala) 
DFD level 2 dari data rule sistem pakar penyakit kanker payudara dapat dilihat pada gambar-6.

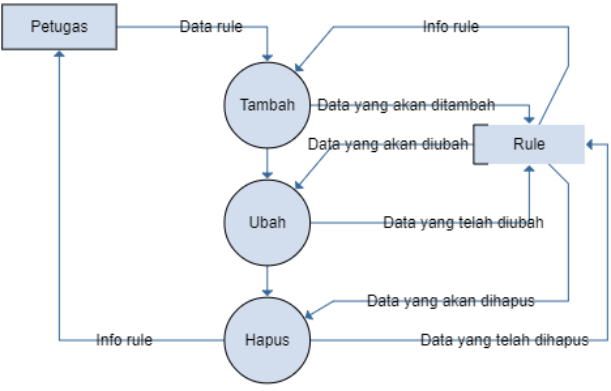

Gambar 6. DFD level 2(rule)

Entity relationship diagram adalah alat pemodelan data utama dan akan membantu mengorganisasi data dalam suatu proyek ke dalam entitas-entitas dan menentukan hubungan antar entitas. Proses memungkinkan analisis menghasilkan struktur basis data yang baik sehingga data dapat disimpan dan diambil secara efisien [10]. Gambar-7 merupakan ERD sistem pakar penyakit kanker payudara.

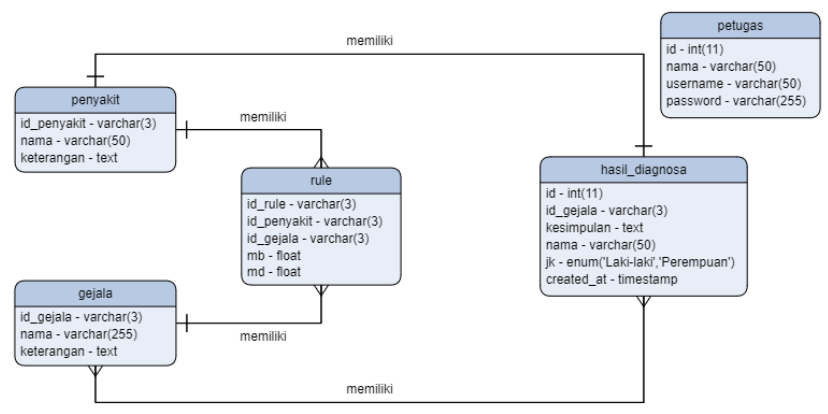

Gambar 7. ERD

\subsection{Implementation and unit testing}

Pada tahap ini, perancangan perangkat lunak di realisasikan sebagai serangkaian program atau unit program. Pengujian melibatkan verifikasi bahwa setiap unit memenuhi spesifikasinya.

\section{Implementasi software dan hardware}

Berikut ialah beberapa komponen hardware dan software yang harus disiapkan dalam pembangunan sistem ini, antara lain:

1. Hardware berupa laptop ASUS X441U dengan spesifikasi intel CORE i3 7th Gen RAM 4 GB dengan sistem operasi Windows 10-64 Bit.

2. Software XAMPP (webserver Apache dan database server MySQL).

\section{Implementasi antarmuka}

Implementasi antarmuka merupakan tahapan dalam memenuhi kebutuhan pengguna dalam berinteraksi dengan sistem yang dibuat. Antarmuka yang baik akan membuat pengguna program menjadi lebih mudah digunakan serta tidak membingungkan, untuk itu peranan antarmuka itu sangat penting. Gambar-8 merupakan perancangan struktur menu digunakan untuk menampilkan menu-menu yang dipakai dalam aplikasi. 


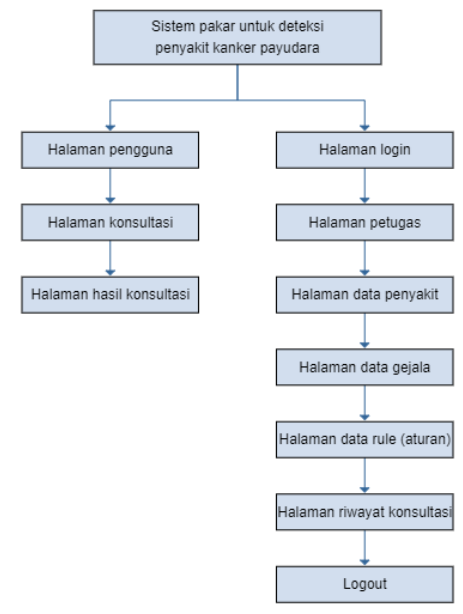

Gambar 8. Struktur menu sistem pakar

\subsection{Integration and system testing}

Pada tahap ini sistem akan dilakukan pengujian dengan menggunakan metode black-box testing dan usability testing. Unit-unit program digabung dan diuji sebagai sebuah sistem lengkap untuk memastikan apakah sudah sesuai dengan kebutuhan perangkat lunak sebelum dapat dikirimkan ke pengguna.

\subsection{Operation and maintenance}

Sistem pakar yang sudah dibangun agar dapat berjalan dengan baik dan tanpa masalah, maka harus dilakukan pemeliharaan. Pemeliharaan meliputi kesalahan-kesalahan yang ditemukan pada saat sistem sedang berjalan, memperbaharui data-data di dalam sistem, peningkatan cara kerja sistem, serta pemeriksaan sistem secara berkala untuk mengantisipasi kesalahan yang terjadi.

\section{HASIL DAN PEMBAHASAN}

Hasil yang diperoleh dari penelitian ini ialah berupa sistem pakar untuk mendeteksi penyakit kanker payudara yang dapat di akses oleh 2 user yang dapat mengakses sistem yaitu petugas dan juga pengguna. Petugas memiliki hak akses sistem secara penuh, meliputi pengolahan data gejala, data penyakit, data rule, serta melihat laporan hasil riwayat konsultasi pengguna. Sedangkan pengguna di sini dapat melihat data gejala yang dimiliki oleh sistem, dan pengguna dapat memilih satu atau lebih dari gejala-gejala yang ada tersebut sesuai dengan yang dialami. Kemudian, pengguna akan mendapatkan laporan hasil konsultasi berupa kemungkinan jenis penyakit kanker payudara yang diderita, saran beserta nilai persentasenya.

\section{Hasil}

Halaman login, ditujukan kepada petugas agar dapat masuk ke dalam sistem, untuk detail antarmuka halaman login dapat dilihat pada gambar-9.

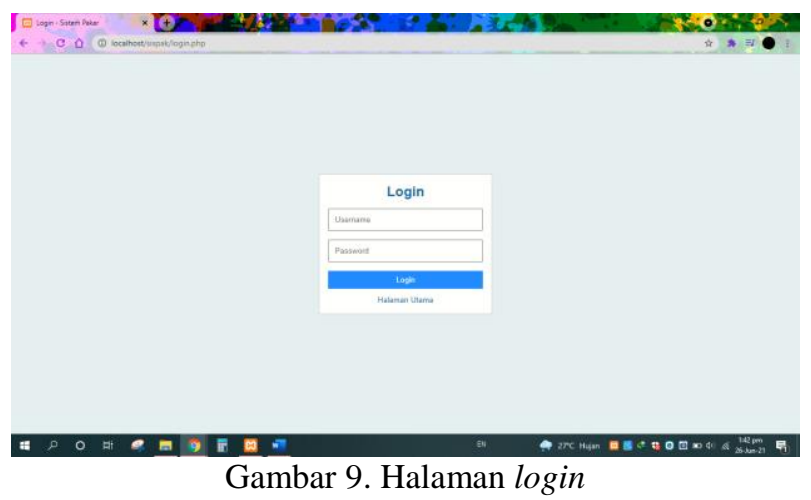


Halaman petugas, berisi tentang menu-menu yang terdapat di dalam sistem, untuk detail antarmuka petugas dapat dilihat pada gambar-10.

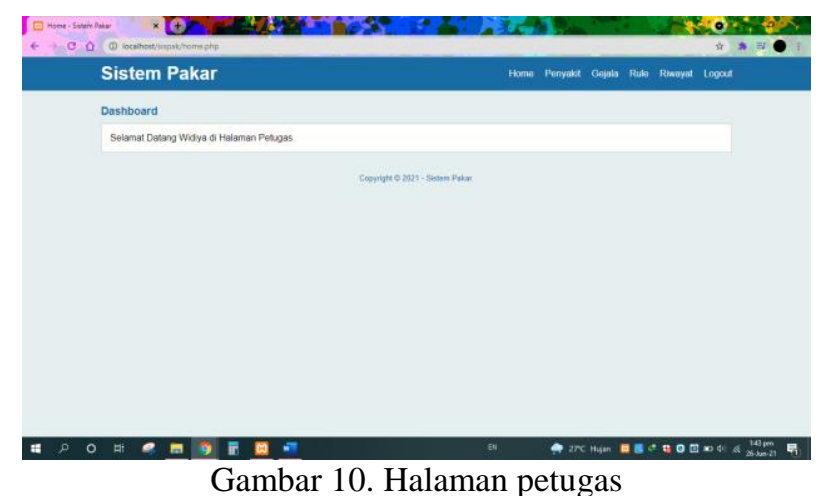

Halaman data gejala, berisi tentang informasi gejala yang terkait di sistem, untuk detail antarmuka halaman gejala dapat dilihat pada gambar-11.

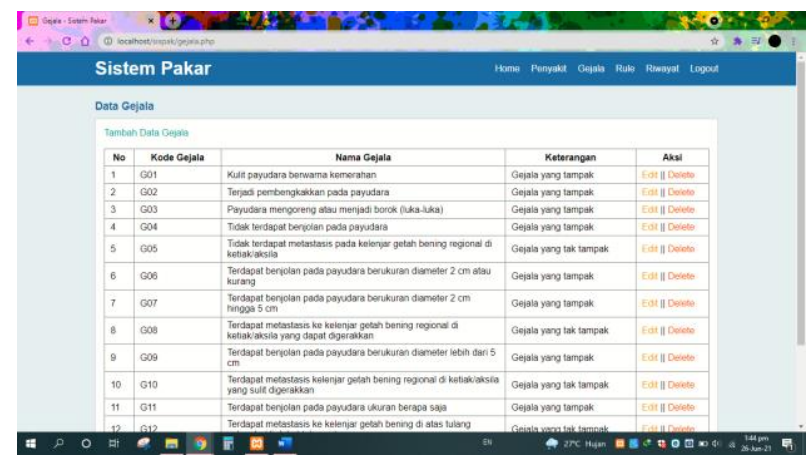

Gambar 11. Halaman data gejala

Halaman data penyakit, berisi tentang informasi penyakit yang terkait di sistem, untuk detail antarmuka halaman penyakit dapat dilihat pada gambar-12.

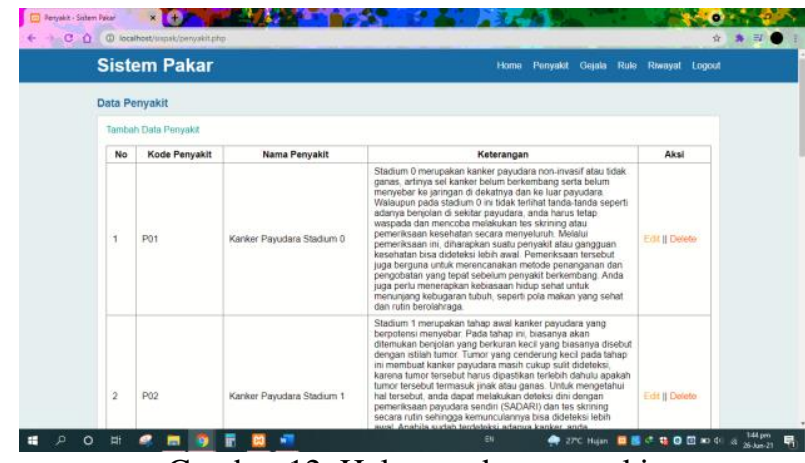

Gambar 12. Halaman data penyakit 
Halaman rule, berisi tentang informasi hubungan data gejala dan data penyakit yang terkait di sistem, untuk detail antarmuka halaman rule dapat dilihat pada gambar-13.

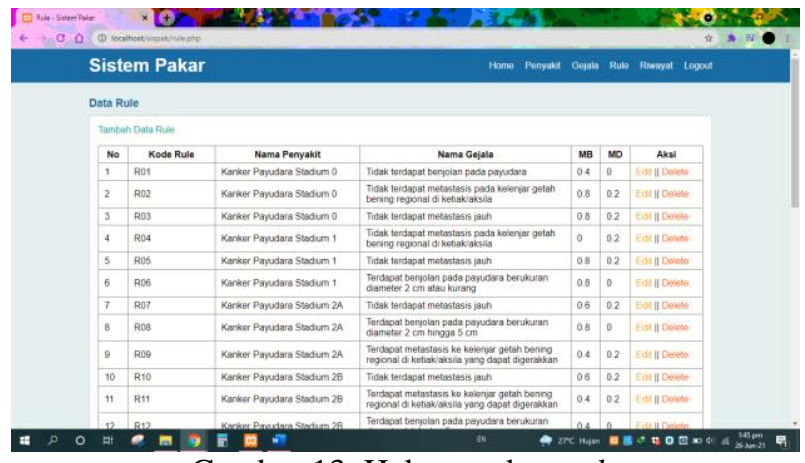

Gambar 13. Halaman data rule

Halaman riwayat, berisi tentang informasi hasil riwayat konsultasi yang telah dilakukan pengguna, untuk detail antarmuka halaman riwayat dapat dilihat pada gambar-14.

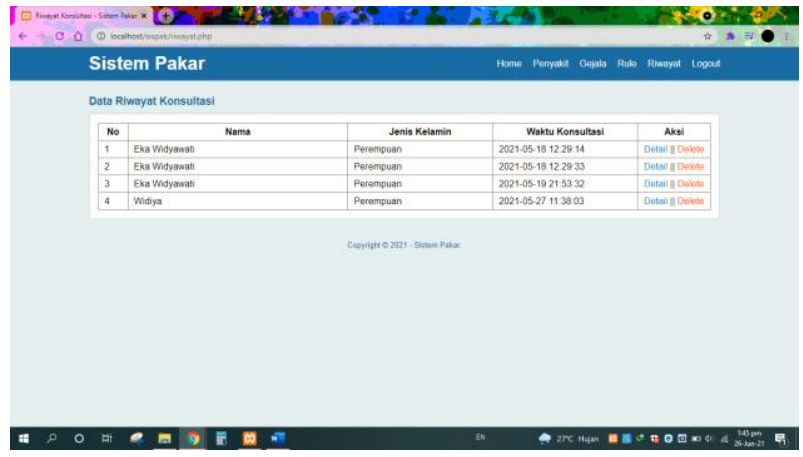

Gambar 14. Halaman riwayat

Halaman ini merupakan tampilan awal ketika sistem pakar dibuka, untuk detail antarmuka halaman pengguna dapat dilihat pada gambar-15.

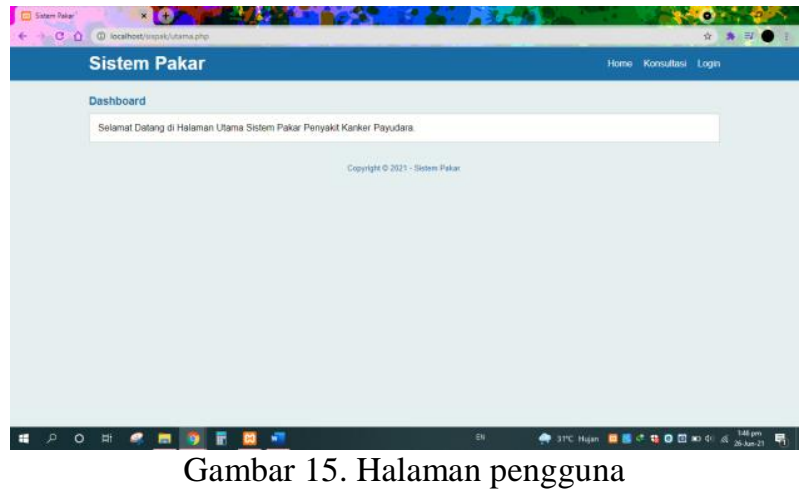

Halaman konsultasi, menampilkan data gejala yang sebelumnya sudah petugas inputkan ke dalam sistem, pengguna diharuskan untuk mengisi data konsultasi terlebih dahulu seperti nama serta jenis kelamin, jika pengguna melewati atau tidak mengisi data konsultasi tersebut, maka sistem akan menampilkan peringatan bahwa pengguna harus mengisi data konsultasinya. Karena sistem membutuhkan data konsultasi tersebut agar dapat melihat riwayat pengguna yang mengakses sistem serta hasill konsultasi yang dilakukan pengguna. Setelah mengisi data konsultasi, pengguna diharuskan memilih minimal 1 gejala yang sesuai dengan yang dialami untuk mendapatkan hasil konsultasi, untuk detail antarmuka halaman konsultasi dapat dilihat pada gambar-16. 


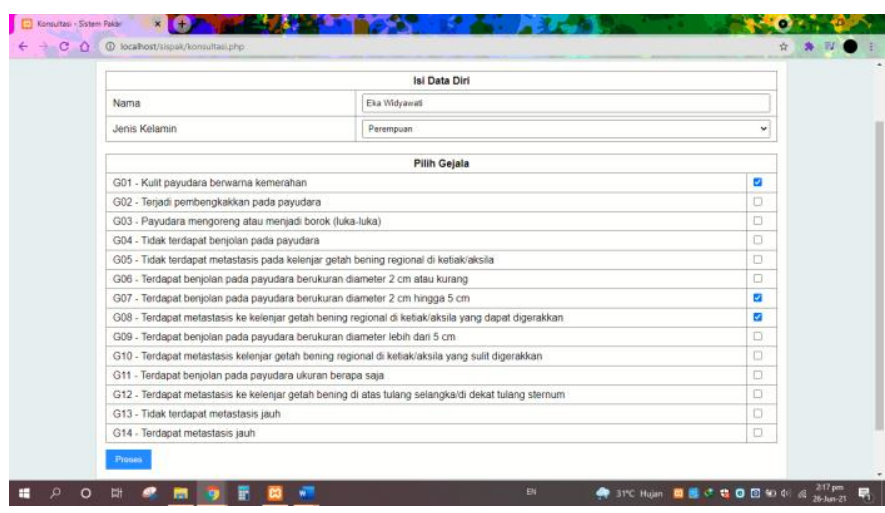

Gambar 16. Halaman konsultasi

Setelah pengguna memilih gejala yang ditampilkan oleh sistem, maka sistem akan melakukan pemeriksaan pada data gejala, data penyakit, dan data rule yang ada di dalam sistem dan melakukan perhitungan dengan menggunakan metode certainty factor untuk mendapatkan laporan hasil konsultasi berupa jenis penyakit kanker payudara yang diderita, saran, serta nilai persentasenya. Perhitungan certainty factor berdasarkan gejala yang dipilih pengguna pada halaman konsultasi tersebut dapat dilihat seperti di bawah ini:

G01 - Kulit payudara berwarna kemerahan

G07 - Terdapat benjolan pada payudara berukuran diameter $2 \mathrm{~cm}$ hingga $5 \mathrm{~cm}$

G08 - Terdapat metastasis ke kelenjar getah bening regional di ketiak/aksila yang dapat digerakkan

Jika dilihat berdasarkan tabel rule di atas, gejala [G01] terdapat pada rule dengan kode penyakit [P06], [P07], [P08] kemudian gejala [G07] terdapat pada rule dengan kode penyakit [P03] dan gejala [G08] terdapat pada rule dengan kode penyakit [P03], [P04]. Dari masing-masing rule tersebut maka dapat dilihat nilai MB dan MD seperti yang ditunjukkan pada tabel 5 di bawah ini:

\begin{tabular}{cccc}
\multicolumn{4}{c}{ Tabel 5. Nilai MB dan MD } \\
\hline Kode & Kaidah Produksi & MB & MD \\
\hline R08 & IF G07 THEN P03 & 0.8 & 0.0 \\
R09 & IF G08 THEN P03 & 0.4 & 0.2 \\
R11 & IF G08 THEN P04 & 0.4 & 0.2 \\
R21 & IF G01 THEN P06 & 0.4 & 0.0 \\
R26 & IF G01 THEN P07 & 0.4 & 0.0 \\
R31 & IF G01 THEN P08 & 0.4 & 0.0 \\
\hline
\end{tabular}

Jika terdapat 2 gejala atau lebih dalam 1 rule penyakit maka perhitungan nilai CFnya ialah:

- $\quad$ IF G07 THEN P03

$$
C F 1=M B-M D=0,8-0,0=0,8
$$

- $\quad$ IF G08 THEN P03

$C F 2=M B-M D=0,4-0,2=0,2$

$C F$ combine $=C F 1+C F 2 *(1-C F 1)=0,8+0,2(1-0,8)=0,84$

Persentase $=C F \times 100 \%=0,84 \times 100 \%=84 \%$

Jika hanya terdapat 1 gejala dalam 1 rule penyakit maka perhitungan nilai Cfnya ialah:

- $\quad$ IF G08 THEN P04

$C F=M B-M D=0,4-0,2=0,2$

Persentase $=C F \times 100 \%=0,2 \times 100 \%=20 \%$

- IF G01 THEN P06

$C F=M B-M D=0,4-0,0=0,4$

Persentase $=C F \times 100 \%=0,4 \times 100 \%=40 \%$

- $\quad$ IF G01 THEN P07

$C F=M B-M D=0,4-0,0=0,4$

Persentase $=C F \times 100 \%=0,4 \times 100 \%=40 \%$

- $\quad$ IF G01 THEN P08

$C F=M B-M D=0,4-0,0=0,4$

Persentase $=C F \times 100 \%=0,4 \times 100 \%=40 \%$

Berdasarkan perhitungan keseluruhan rule penyakit yang berhubungan berdasarkan gejala yang pengguna pilih, maka kemungkinannya ialah pengguna terkena penyakit kanker payudara stadium $2 \mathrm{~A}$ yang memiliki nilai 
persentase terbesar yaitu 84\%. Hasil perhitungan tersebut sesuai dengan output yang ditampilkan oleh sistem pada gambar-17, hal ini berarti sistem telah dapat mendeteksi penyakit kanker payudara berdasarkan gejala yang dipilih oleh pengguna.

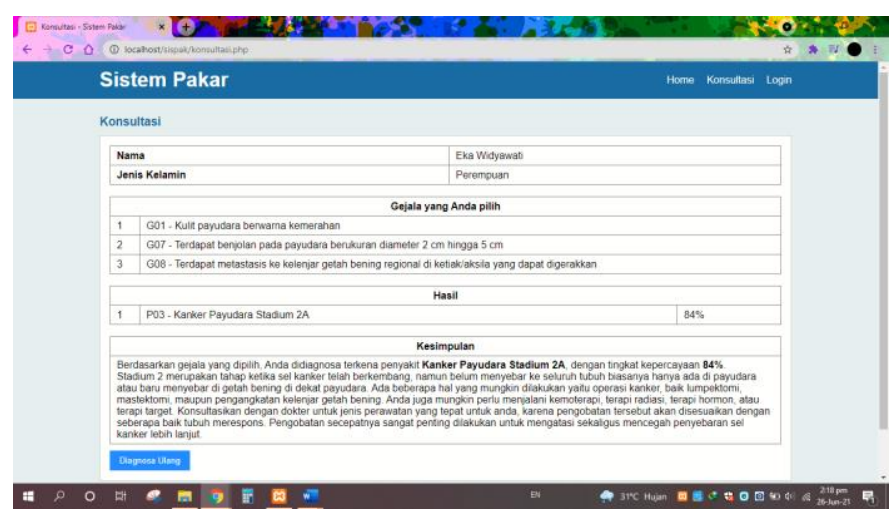

Gambar 17. Halaman hasil konsultasi

\section{Black-box testing}

Black-box testing sering juga disebut sebagai behavioral testing, atau functional testing adalah sebuah metode testing (pengujian) yang dilakukan tanpa pengetahuan detail struktur internal dari sistem atau komponen yang di tes. Black-box testing berokus pada kebutuhan fungsional pada software (perangkat lunak), berdasarkan pada spesifikasi kebutuhan dari software [11]. Berdasarkan rencana pengujian, maka pengujian dengan metode blackbox akan dijelaskan pada tabel-6 dibawah ini:

\begin{tabular}{|c|c|c|}
\hline Input & Output & Status \\
\hline Tombol "Sistem Pakar" & Menampilkan Halaman Pengguna/Petugas & Sesuai \\
\hline Tombol "Home" & Menampilkan Halaman Pengguna/Petugas & Sesuai \\
\hline Tombol "Konsultasi" & $\begin{array}{l}\text { Menampilkan Halaman Konsultasi dan } \\
\text { menampilkan pilihan data gejala }\end{array}$ & Sesuai \\
\hline Tombol "Login" & Menampilkan Halaman Login Petugas & Sesuai \\
\hline Tombol "Proses Konsultasi" & $\begin{array}{l}\text { Memproses inputan pengguna dan menampilkan } \\
\text { Halaman Hasil Konsultasi }\end{array}$ & Sesuai \\
\hline Tombol "Diagnosa Lagi" & $\begin{array}{l}\text { Menampilkan Halaman Konsultasi dan } \\
\text { menampilkan pilihan data gejala }\end{array}$ & Sesuai \\
\hline Tombol "Masuk" & $\begin{array}{l}\text { Memproses username dan password apakah sudah } \\
\text { sesuai atau tidak, jika sesuai akan menampilkan } \\
\text { Halaman Petugas dan jika tidak akan menampilkan } \\
\text { peringatan username dan password salah }\end{array}$ & Sesuai \\
\hline Tombol "Halaman Utama" & Menampilkan Halaman Pengguna & Sesuai \\
\hline Tombol "Gejala" & Menampilkan Halaman Data Gejala & Sesuai \\
\hline Tombol "Penyakit" & Menampilkan Halaman Data Penyakit & Sesuai \\
\hline Tombol "Rule" & Menampilkan Halaman Data Rule & Sesuai \\
\hline Tombol "Riwayat" & Menampilkan Halaman Data Riwayat & Sesuai \\
\hline Tombol "Logout" & $\begin{array}{l}\text { Menampilkan Halaman Login Petugas dan keluar } \\
\text { dari Halaman Petugas }\end{array}$ & Sesuai \\
\hline Tombol "Tambah" & Menampilkan Halaman form tambah data & Sesuai \\
\hline Tombol "Simpan" & $\begin{array}{l}\text { Menyimpan inputan petugas serta mengirim inputan } \\
\text { ke database }\end{array}$ & Sesuai \\
\hline Tombol "Edit" & Menampilkan Halaman form edit data & Sesuai \\
\hline Tombol "Delete" & $\begin{array}{l}\text { Menampilkan peringatan apakah data ini akan } \\
\text { dihapus dan menghapus data dari database }\end{array}$ & Sesuai \\
\hline Tombol "View" & Menampilkan Halaman Detail Riwayat Konsultasi & Sesuai \\
\hline
\end{tabular}

\section{Usability Testing}

Salah satu cara untuk melakukan evaluasi sebuah produk adalah dengan menggunakan teknik usability testing [12]. Usability menjadi faktor yang mempengaruhi sebuah aplikasi dapat dikatakan baik atau tidak. Dalam pengujian usability test, peneliti menyebarkan kuesioner dengan menggunakan google form yang berisi 10 
pertanyaan mewakili kelima aspek usability testing dan disebarkan kepada 50 orang melalui media sosial. Pada tabel-7 merupakan daftar pertanyaan kuesioner berdasarkan kelima aspek usability.

\begin{tabular}{|c|c|c|c|c|c|c|}
\hline No & Pertanyaan & $\begin{array}{l}\text { Sangat } \\
\text { Setuju }\end{array}$ & Setuju & Netral & $\begin{array}{c}\text { Tidak } \\
\text { Setuju } \\
\end{array}$ & $\begin{array}{c}\text { Sangat } \\
\text { Tidak Setuju }\end{array}$ \\
\hline \multicolumn{7}{|c|}{ Learnability } \\
\hline $\begin{array}{l}1 \\
2\end{array}$ & $\begin{array}{l}\text { Apakah sistem mudah untuk anda operasikan? } \\
\text { Apakah informasi pada sistem mudah untuk anda } \\
\text { pahami? }\end{array}$ & & & & & \\
\hline \multicolumn{7}{|c|}{ Efficiency } \\
\hline 1 & $\begin{array}{l}\text { Apakah tulisan (huruf dan ukuran huruf) pada } \\
\text { sistem mudah untuk anda baca? } \\
\text { Apakah fitur (tombol) pada sistem memudahkan } \\
\text { anda dalam mengoperasikannya? }\end{array}$ & & & & & \\
\hline \multicolumn{7}{|c|}{ Memorability } \\
\hline 1 & $\begin{array}{l}\text { Apakah tampilan antarmuka sistem mudah untuk } \\
\text { anda kenali? } \\
\text { Apakah tampilan antarmuka sistem ini menarik } \\
\text { perhatian anda? }\end{array}$ & & & & & \\
\hline \multicolumn{7}{|c|}{ Errors } \\
\hline 1 & $\begin{array}{l}\text { Apakah fitur (tombol) pada sistem bekerja } \\
\text { dengan baik? } \\
\text { Apakah sistem menampilkan halaman dengan } \\
\text { cepat? }\end{array}$ & & & & & \\
\hline \multicolumn{7}{|c|}{ Satisfaction } \\
\hline 1 & $\begin{array}{l}\text { Apakah anda puas dengan informasi yang } \\
\text { diberikan sistem? } \\
\text { Apakah anda akan merekomendasikan sistem ini } \\
\text { kepada rekan-rekan yang lain? }\end{array}$ & & & & & \\
\hline
\end{tabular}

Setelah dilakukan pengisian kuesioner, maka selanjutnya akan dilakukan perhitungan hasil kuesioner dengan menggunakan rating scale [13].

Keterangan:

Sangat setuju $=5$, Setuju $=4$, Netral $=3$, Tidak setuju $=2$, Sangat tidak setuju $=1$

Skor hasil pengumpulan data $=2125$

Skor tertinggi tiap butir $=5$

Jumlah responden $=50$

Jumlah butir $=10$

$$
p=\frac{\text { skor hasil pengumpulan data }}{\text { skor terting gi tiap butir } * \text { jml responden } * \text { jml butir }} \times 100 \%=\frac{2125}{2500} \times 100 \%=85 \%
$$

Selanjutnya data hasil perhitungan tersebut akan di kategorikan dengan menggunakan skala interpretasi. Skala interpretasi yang digunakan dapat dilihat pada gambar-18 di bawah ini.

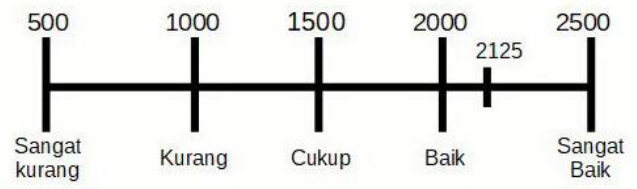

Gambar 18. Skala interpretasi

Berdasarkan skala interpretasi di atas, nilai skor hasil pengumpulan data terdapat dalam kategori interval Baik - Sangat baik. Hal ini dapat diartikan bahwa website atau sistem yang dibuat sudah memenuhi kelima aspek usability testing yaitu (learnability, efficiency, memorability, errors, dan satisfaction).

\section{PENUTUP}

\section{Kesimpulan}

Berdasarkan hasil penelitian dan pembahasan dapat diambil kesimpulan bahwa, metode forward chaining dan certainty factor dapat diterapkan pada sistem pakar untuk mendeteksi kanker payudara sehingga dapat memberikan hasil konsultasi dengan cepat beserta nilai persentase keyakinan dari penyakit berdasarkan gejala 
yang dipilih oleh pengguna. Serta, berdasarkan pengujian black-box testing dan usability testing telah didapatkan hasil yang sudah sesuai dan cukup baik.

\section{Saran}

Saran penulis untuk pengembangan sistem pakar selanjutnya ialah, diharapkan aplikasi sistem pakar berbasis website ini dapat dikembangkan ke dalam aplikasi mobile berbasis android, iOS, windows mobile. Diharapkan juga, dapat memperluas penyakit yang di diagnosa, tidak hanya penyakit kanker payudara saja dan untuk pengambilan hasil diagnosa dapat menggunakan metode lainnya, sehingga menjadi alternatif pembanding untuk mengetahui metode mana yang lebih tepat dan akurat.

\section{DAFTAR PUSTAKA}

[1] S. Kusumadewi, Artificial Intellegence (Teknik dan Aplikasinya). Yogyakarta: Graha Ilmu, 2003.

[2] S. Ariani, Stop Kanker. Yogyakarta: Istana Media, 2015.

[3] Yafi, "Rancang Bangun Sistem Pakar Deteksi Penyakit Kanker Pada Wanita Berbasis WAP Pada Perangkat Mobile," Universitas Diponegoro, 2012.

[4] R. Pambudi, “Aplikasi Sistem Pakar Diagnosa Penyakit Kanker Menggunakan Metode Certainty Factor, ” Universitas Muhammadiyah Sidoarjo, 2015.

[5] A. S. Rosa, dan M. Shalahuddin, Rekayasa Perangkat Lunak Terstruktur dan Berorientasi Objek. Bandung: Informatika, 2013.

[6] I. Sommerville, Software Engineering 9th Edition. United States: Addison-Wesley, 2011.

[7] Edge SB, and Compton CC, "The American Joint Commite on Cancer: The 7th edition of the AJCC cancer staging manual and the future of TNM," Ann Surg Oncol, vol. 17, no. 6, pp. 1471-1474, 2010, doi: 10.1245/s10434-010-0985-4.

[8] D. A. Puspitawati, "Sistem Pakar Diagnosis Penyakit Kanker Payudara Dan Cara Penanganannya," TECHNO Nusa Mandiri, vol. 15, no. 2, pp. 129-136, 2018, doi: 10.33480/techno.v15i2.22.

[9] N. Dengen, dan H. R. Hatta, "Perancangan Sistem Informasi Terpadu Pemerintah Daerah Kabupaten Paser," J. Inform. Mulawarman, vol. 4, no. 1, pp. 47-54, 2009, doi: 10.30872/jim.v4i1.27.

[10] Simarmata, Janner, dan P. Imam, Basis Data. Yogyakarta: Andi Offset, 2010.

[11] Romeo, Testing dan Implementasi Sistem. Surabaya: STIKOM, 2003.

[12] J. Rubin dan D. Chisnell, Handbook of Usability Testing 2nd Edition. United States: Boulevard Wiley, 2008.

[13] Sugiyono, Metode Penelitian Pendidikan (Pendekatan Kuantitatif, Kualitatif, dan R\&D). Bandung: Alfabeta, 2015. 